\begin{tabular}{|c|c|c|}
\hline$\underbrace{}_{\text {INESEG }}$ & $\begin{array}{l}\text { INTERNATIONAL } \\
\text { ENGINEERING, } \\
\text { SCIENCE AND } \\
\text { EDUCATION } \\
\text { GROUP }\end{array}$ & $\begin{array}{l}\text { Middle East Journal of Science } \\
\text { (2017) 3(2): } 98 \text { - } 106 \\
\text { Published online December 25, } 2017 \quad \text { (http://dergipark.gov.tr/mejs) } \\
\text { doi: } 10.23884 / \text { mejs.2017.3.2.04 } \\
\text { ISSN: } 2536-5312 \\
\text { Received: October 23, } 2017 \quad \text { Accepted: December 15, } 2017\end{array}$ \\
\hline
\end{tabular}

\title{
AGROMYZID (DIPTERA) SPECIES AND THEIR PARASITOIDS IN BATMAN PROVINCE, TURKEY
}

\author{
Selime ÖLMEZ BAYHAN*I Mehmet Kaplan ${ }^{2}$ Erol Bayhan ${ }^{1}$
}

${ }^{1}$ Dicle University, Agricultural Faculty, Department of Plant Protection, DIYARBAKIR, TURKEY

${ }^{2}$ Diyarbakır Plant Protection Research Institute, DIYARBAKIR, TURKEY

*Corresponding author: solmez@dicle.edu.tr

\begin{abstract}
This study was carried out during 2010 and 2012 in province of Batman, Turkey, for surveying the agromyzid fauna. The specimens were collected by rearing of the mine-infested leaves of different cultivated and non-cultivated host plants. Seven species belonging to three genera of the subfamily of Agromyzinae and two species belonging to one genera of subfamily of Phytomyzinae were collected. These species were Agromyza albitarsis, Chromatomyia horticola, Liriomyza bryoniae, Liriomyza cicerina, Liriomyza huidobrensis, Liriomyza strigata, Liriomyza trifolii, Phytomyza affinis and Phytomyza orobanchia. In this study, among all determined parasitoids, 3 species were belonging to family of Braconidae and 1 species were belonging to the family of Eulophidae and Aphididae each. Among them, Diglyphus isaea Walker was the most widespreading species.
\end{abstract}

Key Words: Agromyzidae, Parasitoid, Cultivated and Non-Cultivated Areas, Batman

\section{Introduction}

Leaf miners species belonging to Agromyzidae (Diptera) family damage by feeding on different plants. However adult females of the species belonging to this family cause the degradation of chlorophyll by inserting their ovipositor into leaf tissue during egg laying. This results whitish pinhead-size dots on the leaf surface. With a life span of 7-10 days, an adult female can cause as many as 120-140 white dots. This type of damage halts photosynthesis function and reduces the marketing values of crops significantly, especially in ornamental plants. By feeding and opening galleries in the tissue between two layers of leaves epidermis, pest larvae feed on mesophyll and cause the disappearance of mesophyll and resultlng the formation of whitish spots. Such leaves cannot photosynthesis and therefore yield and quality 
losses occur. Many Agromyzidae species are monofag. Oligofag types are also available. Very few of Agromyzidae species are polifag and have a wide host range. Ferns, important group of flowering plants, monocotyledons and Dicotyledons are species of this family [26].

In a very rich flora of our country, so far, comprehensive studies on the species of this family have been done in recent years. The presence of 175 species of Agromyzidae are revealed in our country [13, 30, 34, 2, 28, 8, 11, 17, 20]. The research done on Agromyzidae in the anatolia Region Application area and vegetables production of Diyarbakır, Mardin and Şanlıurfa province revealed 28 species, and of these species, L. trifolii, and L. L. Chicherina strigata species were determined to be important $[6,8,9]$.

This study was conducted to detect harmful and parasites species of family Agromyzidae in the agricultural and non-agricultural areas of Batman.

\section{Material and Methods}

The main material of the research was Agromyzinae and Phytomyzinae subfamilies belong to the Agromyzidae family, which were collected in cultivated and wild plants in 20102012 in Batman Center, Beşiri, Gercüş, Hasankeyf, Kozluk and Sason of Turkey. The samples collected from the research areas were labelled with the name, place and date of the host, and brought to the laboratory in polyethylene bags. In the laboratory, they were transferred to transparent plastic jars and to moist soil containing pots.

The abdomen of the obtained male subjects was individually placed in glass tubes containing $10 \% \mathrm{KOH}$ to soften and clear the body with a fine-tipped needle under a stereoscopic binocular microscope. Then, these tubes were placed in a $15 \mathrm{~cm}$ metal container filled with water on the electric cooker and the abdomen in the tubes held in this environment was taken with the help of a fine pipette for 15-20 minutes after the water was boiled and transferred to the pit plate containing glacial acetic acid. It was left in this environment for 5 minutes. Then, another pit with $96 \%$ alcohol was transferred into the slide, where it was left for 5 minutes, and then removed from the abdominal genital organs with the help of a fine-tipped needle. Diagnosis was made according to Spencer [23, 24, 25, 26, 27].

\section{Results and Discussion}

In this study, 9 agromyzid species were determined belonging to 2 subfamily and 5 genera.

\section{Subfamily: Agromyzinae}

\section{Species: Agromyza albitarsis Meigen, 1830}

Synonym: Agromyza lygophora Hering, 1937

The wing length was 2.2-2.6 mm with matte gray colour. Frons, all antenna segments and mesonotum are black colored, 3rd antenna segment is round. 
Distribution: Canada, Western and Northern European countries [25].

this species was detected first in İzmir of our country [13].

Material examined: Gercüş, Hasankeyf, Beşiri, Kozluk and Sason from Populus sp. This species was found heavily.

Parasitoid: Opius basalis, Cirrospilus lyncus, C. vittatus, Diglyphus isaea, Pnigalio soemius $[8,10]$.

In this study, parasitoid was not detected.

\section{Subfamily: Phytomyzinae}

Species: Chromatomyia horticola (Goureau, 1851)

Synonym: Phytomyza atricornis Meigen, 1935; Phytomyza bidensivora Séguy, 1951; Phytomyza cucumis Macquart, 1854; Phytomyza fediae Kaltenbach, 1860; Phytomyza Vimmer, 1928; Phytomyza linariae Kaltenbach, 1862; Phytomyza meliloti Brischke, 1882;

The wing length was 2.2-2.7 mm and black. Frons were dark yellow and orange in color with 2 upper and 1 bottom orbital bristles. 1st and 2nd antenna segments are yellow and 3rd segment is black colored, small and round.

Distribution: It is a cosmopolitan species in the world [25]. Turkey [3, 4, 19,13].

[1] In this study, Gercüş, Hasankeyf, Beşiri, Kozluk and Sason from Sinapis arvensis L., Turgenia latifolia (L.), Sonchus sp., Xanthium sp., Papaver spp., L. esculentum ve Vicia sp. It was found dense and widespread on the plants.

Parasitoid: Pediobius acantha, Chrysocharis liriomyzae Delucchi, Cirrospilus vittatus, Diglyphus isaea Walker, D. minoeus Walker, Neochrysocharis formosa Walker (Hymenoptera: Eulophidae); Opius ambiguus Wesmeal, O. exiguus Wesmeal, O. osogovensis Fischer and $O$. pallipes Wesmeal (Hymenoptera: Braconidae) [1, 21, 30, 8].

O. pallipes from Sinapis arvensis and Sonchus sp.; D. isaea from L. esculentum and Vicia sp.

\section{Species: Liriomyza bryoniae (Kaltenbach 1858)}

Synonym: Agromyza bryoniae (Kaltenbach 1858), Liriomyza solani (Hering 1927), Liriomyza hydrocotylae (Hering 1930), Liriomyza mercurialis (Hering 1932), Liriomyza triton (Frey 1945), Liriomyza citrulli (Rohdendorf 1950), Liriomyza nipponallia (Sasakawa 1961).

Mesonotum is a small species in bright black color. The frons are bright yellow in color and the gena form a elongated circle under the eye. The third antenna segment is bright yellowish.

Distribution: Croatia, Czech Republic, Denmark, Estonia, Finland, France, Germany, Greece, Hungary, Italy, Japan, Republic of Korea, Nepal, Taiwan, Turkmenistan, Vietnam, Albania, Morocco, Morocco, Latvia, Lithuania, Malta, Moldova, Netherlands, Norway, Poland, 
Portugal, Romania, Russian Federation, Slovenia, Spain, Sweden, Ukraine, United Kingdom $[29,22,20]$. This was also recorded in the Eastern Mediterranean region of our contry [30].

In this study Lycopersicum esculentum and Heliothropium were detected in Beşiri and Kozan; Citrullus vulgaris and Cucumis melo were found in Sason.

Parasitoid: O. pallipes, O. gafsaensis and D. isaea [31, 8].

D. isaea was found from L. bryoniae.

\section{Species: Liriomyza cicerina (Rondani, 1875)}

Synonym: Liriomyza ononidis de Meijere 1925

Liriomyza trichophthalma (Hendel 1931)

The wing length is 1.3-1.6 mm. Head, mesonotum and 3rd antenna segment are black, 1 st and 2nd antenna segments are yellowish.

Distribution: Africa, Asia and all European countries [24, 18, 20]. It is also common in our country $[19,14,30,8]$.

In this study L. cicerina, in Besiri, Kozluk and Lens sp. and Cicer arietinum was recorded in Sason districts.

Parasitoid: Diauliropsis arenomia, Neochrysocharis albipes Kurdjumov, N. Ambitiosa, N. sericae, D. isaea, O. pallipes, O. monilicornis and O. exiguus were recorded parasitoids [32, $8]$.

In this study, D. isaea and $O$. pallipes were obtained from the harmful species.

\section{Species: Liriomyza huidobrensis (Blanchard, 1926)}

Synonym: Agromyza huidobrensis (Blanchard, 1926), Liriomyza cucumifoliae (Blanchard, 1938), Liriomyza langei (Frick, 1951), Liriomyza decora (Blanchard, 1954), Liriomyza dianthi (Frick, 1958)

The wing length is $1.7-2.25 \mathrm{~mm}$ and the shiny black color. Frons are yellowish in color and have 2 bottom and upper orbital bristle. Mesonotum is a bright black color; The 3rd antenna segment is orange in color and the 1 st and 2 nd antenna segments are orange or brownish in color.

Distribution: Central America, South America, North America, Argentina, Brazil, Chile, Colombia, Peru, Venezuela, Belgium, Netherlands and Israel are recorded [25, 33]. It has been reported in Turkey [33, 34, 28].

In this study, this species were identified on Capsicum annuum in the central and Beşiri; on Cucumis sativus from Sason districts of Batman 
Parasitoid: Parasitoids of $L$. huidobrensis have been reported in D. isaea, D. poppoea, D. crassinervis, D. minoeus, Hemiptarsenus varicornis (Hym: Eulophidae) and Dacnusa spp. (Hym .: Braconidae) $[15,33,5,10]$.

In this study, D. isaea was collected from the Capsicum annuum in Beşiri.

\section{Species: Liriomyza strigata (Meigen, 1830)}

Synonym: Agromyza pumila Meige

Agromyza violae Curtis, 1844

Agromyza galeopsios Hardy, 1853

The wing length 1.8-2.1 mm. It is a black colored species in its length. Frons, orbital area and all antenna segments are yellowish. The 3rd antenna segment is round and covered with hair.

Distribution: It was reported in European countries, Russia, Uzbekistan and Kyrgyzstan [25]. It has been also reported in many places in Turkey $[13,30,7,8,28,10]$.

In this study the species were obtained from Cucumis melo, Phaseolus vulgaris in Central, Beşiri and Kozluk; Capsicum annuum and Lycopersicon esculentum in Gercüş; Solanum melongena in Sason.

Parasitoid: Dacnusa discolor, D. maculipes, Chorebes daimenes, O. exiguous, O. levis, O. pallipes, O. propodealis, Halticoptera smaragdina, Chrysocharis albicans, C. pubicornis and $P$. acantha as parasitoids [25].

In this study, D.isaea, O. lonicerae, O. exiguous ve Aphidius ervi parasitoid species were detected.

\section{Species: Liriomyza trifolii (Burgess, 1880)}

Synonym: Agromyza phaseolunata Frost, 1943; Liriomyza alliovora Frick, 1955; Oscinis trifolii Burgess, 1880

Wing length is $1.3-2.3 \mathrm{~mm}$ and greyish-black. Females are slightly bigger than males. The 3rd antenna segment with head and eyes and femur is yellow in color.

Distribution: It has been reported in USA, France, Holland, Italy, Canada, Hungary, Asia and Africa countries [24]. This species is also common in our country [30, 2, 8].

In this study, Phaseolus vulgaris L., Solanum melongena L., Capsicum annum, Citrullus vulgaris collected from in Beşeri and Hasankeyf, Dahlia sp. ve Tribulus terestris in Sason, Lycopersicum esculentum in Gercüş, Papaver sp., Lactuca sativa ve Sonchus sp. in Kozluk. It was found to be widespread and intense in all the areas of Batman.

Parasitoid: Epiclerus nomocerus, Dacnusa sibirica, D. isaea, D. minoeus, D. begini, D. pachyneurus, Closterocerus formosus, O. ambiguus; O. exiguus;O. gafsaensis; O. lonicerae, O. osogovoensis; O. pallipes; Chrysonotomyia smaragdula, N. ambitiosa;N. albipes; N. 
formosa; N. sericae; P. acantha; Sympiesis gordius, Halticoptera patellana, Hemiptarsenus zilahisebessi as parasitoids [12, 16, 30, 35, 8, 10].

In this study, D. isaea, O. exiguus, O. pallipes and Aphidius ervi (Aphidiidae) were detected parasitoids.

\section{Species: Phytomyza affinis Fallen, 1823}

The wing width is $1.7-2.2 \mathrm{~mm}$. Mesonotum matt black lateral parts and notopleural depression yellow. Acrosticals in 2-4 rows, coxae 1 yellow basally, II-III blackish. Distribution: It occure in European countries [25]. It was also found in Şanliurfa province of the country [8].

In this study, it was collected from Senecio sp. and Mentha sp. in Beşiri and Sason.

Parasitoid: There is no record as parasitoid of P. affinis.

In this study, no parasitoid species were found.

\section{Species: Phytomyza orobanchia Kaltenbach, 1864}

The wings are 2.3-2.5 mm long and grayish black. The frons, which are light yellow or orange, protrude above the eye and have 2 upper and 1 bottom orbital bristle. The side of mesonotum, scutellum and thorax is grayish black.

Distrubition: U.S., Afghanistan, Bulgaria, Ethiopia, Iraq, Spain, Italy, Canada, Malta, Egypt, Hungary [25].

Samsun, İzmir, Bursa, Balıkesir, Çanakkale, Diyarbakır, Şanlıurfa [14, 7, 13, 8].

In this study, it was found on Orobanche spp. in Hasankeyf and Beşiri.

Parasitoid: Sphegigaster orobanchiae (Hym.:Pteromalidae) and Aprocetus sp. (Hym.: Ichneumonidae) as parasitoids [24, 8].

In this study, none of parasitoid were found.

\section{Conclusion}

Seven species belonging to three genera of the subfamily of Agromyzinae and two species belonging to one genera of subfamily of Phytomyzinae were found.

In the survey studies, adults of Agromyzidae were started to come out in March and increased in May and the end of April. The population decreased with increasing of temperature. The higher populations were higher in especially areas with higher humidity and lower populations was observed in areas where gets much sunlight. Because of unirrigated farming for many years, less plant diversity, less soil and air humidity and the lack of high species diversity, fewer species were identified in the study area compared to the other regions, especially the Aegean region. 
In the study, higher Agromyzidae populations have been identified on the cultivated plants including melons, beans, tomatoes, peppers and eggplant and chickpea. The most common species of Agromyzidae was determined to be L. trifolii.

Five parasitoids species were detected, of which, D. isaea (Hym.: Eulophidae) was the most common and numerous. Being widespread with a high density, this parasitoid species indicates that it is effective on the Agromyzidae. Especially in recent years, mainly biological control was included into the "integrated pest management" and in organic farming practices. Therefore, conducting new studies to demonstrate the relationships between this pest and beneficial species in the region will be very important for future biological control applications.

\section{Acknowledgements}

This work is supported by Dicle University Scientific Research Projects (DUBAP) Unit, Project No. 08.ZF.58. The authors are grateful to the DUBAP Unit for their financial support.

\section{References}

[1] Bene, G., Bene G.D. (1989). Natural enemies of Liriomyza trifoIii (Burgess), Chromatomyia horticola (Goureau) and Chromatomyia syngenesiae Hardy (Diptera: Agromyzidae) in Tuscany. Redia, 72 (2): 529-544.Cevat, H.N.,1990. Nieuwe mineervlieg veroorzaakt veel schade ; Samen situatie beheersbaar maken. Vakblad voor de Bloemisterij, 9: 38-41.

[2] Civelek, H.S. (1998). İzmir İlinde Bulunan Agromyzidae (Diptera) Familyasına Bağlı Türler Üzerinde Sistematik Araştırmalar., Ege Üniversitesi Fen Bilimleri Enstitüsü Bitki Koruma Anabilim Dalı Doktora Tezi Civelek ve Demirkan.

[3] Civelek, H.S., Önder, F. (1999). İzmir İlinde Bulunan Galerisineğiği (Diptera: Agromyzidae) Türlerinin Doğal Düşmanlarının Saptanması Üzerinde Araştırmalar. Türkiye 4. Biyolojik Mücadele Kongresi, 26-29 Ocak 1999, Adana.

[4] Civelek, H.S. (2002). New records for the Turkish Agromyzidae (Diptera) from Mugla Province, Western Turkey. Insecta Mundi, 16: 49-55.

[5] Civelek, H.S., Yoldaş Z., Weintraub P.G. (2002). Parasitoid complex of Liriomyza huidobrensis. Phytoparasitica, 30: 285-287.

[6] Civelek, H.S. (2004). Two new records for the Turkish Agromyzidae (Diptera) fauna. Türk.entomol.derg., 28: 1-10.

[7] Civelek, H.S., Tonguç, A., Özgül, O., Dursun, O., (2007). Contributions to The Turkish Agromyzidae (Diptera) Fauna from Anatolian Part of Turkey, with sixteen New Records. Mitt. Internat. Entomol: In review

[8] Çıkman, E., Uygun N. (2003). Şanlıurfa ilinde tarım ve tarım dışı alanlarda saptanan galeri sineği (Diptera: Agromyzidae) türleri ve parazitoitleri. Türkiye Entomoloji dergisi, 27(4):305318 
[9] Çıkman, E., Civelek, H.S. (2005). Contributions to the Leafminer Fauna (Diptera: Agromyzidae) from Turkey, with Four New Records. Phytoparasitica, 33(4): 391-396.

[10] Çıkman, E. (2012). Parasitoids of the leafminers (Diptera: Agromyzidae) from Elazığ Province, Turkey African J. Agricultural Research Vol. 7(12), pp. 1937-1943.

[11] Dursun, O., Eskin, A., Atahan, T. (2010). Contributions to the Turkish Agromyzidae (Diptera) fauna with ten new records. Türk. entomol. derg., 2010, 34 (3): 299-306.

[12] Franco, E., Panis, A. (1991). Epiclerus nomocerus (Masi) (Hym., Tetracampidae), nouveau parasitoide de Liriomyza trifolii Burgess (Dip., Agromyzidae) en culture sous serre. Bulletin. Section Regionale Ouest Palaearctique, Organisation Internationale de Lutte Biologique. 14:125-133

[13] Giray, H. (1980). Türkiye'de bitki yapraklarında galeri açan böcekler faunasına ait ilk liste İle Bunların Konukçu ve Önemlilerinin Galeri Şekilleri Hakkında Notlar. E.Ü. Ziraat Fak. Yayınları, No. 374, Bornova, İzmir,106 s.

[14] Giray, H., Nemli, Y. (1983). izmir llinde Orobanche'nındogal dusmam olan Phytomyza orobanchia Kalt. (Diptera: Agromyzidae)'nm morfolojik karakterleri, kisa biyolojisi ve etkinligi uzerinde arastirmalar. Turk. Bit. Kor. Derg., 7 (3): 183-192.

[15] Godinho, M., Mexia A. (2000). Leafminers (Liriomyza sp.) importance in greenhouses in the Oeste region of Portugal and its natural parasitoids as control agents in IPM programs. Integrated Control in Protected Crops, Mediterranean Climate IOBC wprs Bulletin, 23 (1): 157161.

[16] Heinz, K.M, Nunney L., Parrella M.P. (1993). Toward predictable biological control of Liriomyza trifolii (Diptera:Agromyzidae) infesting greenhouse cut chrysanthemums. Environ. Entomol.,22(6):1217-1233.

[17] Hepdurgun, B., Civelek, H. S., Turanlı T., Dursun O. (2007). Türkiye Agromyzidae (Diptera) faunasına katkılar. Türkiye Entomoloji derigisi, 31 (2): 153-159

[18] Kolesík, P., Pastucha L. (1992). Chickpea leafminer Liriomyza cicerina (Rondani, 1875) [Diptera, Agromyzidae] - a new species of Czecho-Slovak fauna. Biológia (Bratislava) 47: 439440.

[19] Lodos, N. (1962). Ege' de nohutlara zarar veren iki sinek türü : Liriomyza cicerina Rond. ve Phytomyza atricornis Meig. Bitki Koruma Bült. 2 (10) : 44-48.

[20] Martinez, M., J.P. Chambon (1983). Preliminary observations on a new cereal leafminer Liriomyza orbona (Meigen), Diptera, Agromyzidae (French with English abstract). Defense des Vegetaux, 1983, No. 220: 95-100. Naresh and Malik, 1989

[21] Paik, J.C., (1991). Notes on some Entedoninae (Hymenoptera, Chalcidoidea, Eulophidae) in Korea. Insecta-Koreana, 8: 60-75

[22] Rohdendorf BB (1950). A new pest of water-melon - the mining fly Liriomyza citrulli Rohdendorf, sp. n. (Diptera, Agromyzidae). Entomologiceskoe Obozrenie 31: 82-84. 
[23] Spencer, K.A. (1972). Diptera Agromyzidae. Handbooks for the Identification of British Insects, 10. 1-136. Royal entomological society of London.

[24] Spencer, K.A. (1973). Agromyzidae (Diptera) of economic importance. The Pitman Press, G.Britain, $418 \mathrm{~s}$.

[25] Spencer, K.A. (1976). The Agromyzidae (Diptera) of Fennoscandia and Denmark. Fauna Ento. Scandinavica, 5 (1-2): 1-606.

[26] Spencer, K.A. (1980). Host specialization in the world Agromyzidae (Diptera). Kluver Academic Publishers, Netherland, 444 s.

[27] Spencer, K.A. (1990). Host specialization in the world Agromyzidae (Diptera). Kluver Academic Publishers, Netherland, 444 s.

[28] Ulusoy, M. R., Civelek H. S., Bayhan E., Ölmez Bayhan S. (2003). Determination Species of The Agromyzidae (Diptera) on Cultivated Plants in The East Mediterranean Region, Turkey”, Ç. Ü. Ziraat Fakültesi Dergisi, 18 (4): 89-92.

[29] Utech, L. (1962). Blatminen und Pflanzengallen aus Albanien und dem Kaukasus. Dt. Ent. Z. (N.F). 9:229-235

[30] Uygun, N., Polatöz Z., Başpınar H. (1995). Doğu Akdeniz Bölgesi Agromyzidae (Diptera) familyası türleri üzerinde faunistik çalışmalar. Türk. Entomol. Derg., 19 (2):123-136.

[31] Volkov, O. G. (1997). Alternative hosts of naturel enemies of the nightshade leafminer. Zashchita Karantin Rastenii, 10: 19-20.

[32] Wiegand, S. (1990). Insect pests of chickpea in the Mediterranean area and possibilities of resistance. Options Méditerranéennes. Série A, Séminaires Méditerranéees No 9:73-76

[33] Weintraub, P.G. (2001). Effects of cyromazine and abamectin on the pea leafminer Liriomyza huidobrensis (Diptera: Agromyzidae) and its parasitoid Diglyphus isaea (Hymonoptera: Eulophidae) in potatoes. Crop Protection, 20: 207-213.

[34] Yabaş, C., H.S. Civelek, A. Ulubilir (1995). Türkiye Agromyzidae faunası için yeni bir yaprak galerisineği, Liriomyza huidobrensis (Blanchard, 1926). Türk. Entomoloji Derg., 19 (2): 117-122.

[35] Yaşarakınc1, N., Hıncal P. (1997). The Research on determining the pests and beneficial species and their population densities on the tomato, cucumber, pepper and lettuce glasshouses in İzmir. Bit. Kor. Bül., 37 (1-2): 79-89. 